\title{
Set of stress biomarkers as a practical tool in the assessment of multistress effect using honeybees from urban and rural areas as a model organism: a pilot study
}

\author{
Łukasz Nicewicz $^{1}$ (D) $\cdot$ Agata W. Nicewicz $^{1} \cdot$ Alina Kafel $^{1} \cdot$ Mirosław Nakonieczny $^{1}$
}

Received: 24 June 2020 / Accepted: 20 October 2020 / Published online: 30 October 2020

(C) The Author(s) 2020

\begin{abstract}
A decrease among honey bee populations (Apis mellifera) in the traditional apiaries has been observed in recent years. In light of this negative phenomenon, urban beekeeping seems to be an appropriate alternative solution for the bee population in reducing the toxic effects of a large number of pesticides that are commonly used in agricultural ecosystems. Despite the rapid development of urban beekeeping, there is little information regarding the different aspects of the defense effectiveness of bees from the urban and rural areas. The study was aimed to show whether honey bees from these two locations differ in the level of the valuable biomarkers of stress exposure helpful in establishing which bees, from urban or rural areas, are under greater environmental pressure. For this purpose, foragers from an urban rooftop apiary and a traditional rural apiary were collected. The chosen biomarkers were measured in various tissues of bees. The activity of glutathione $S$-transferase and acetylcholinesterase, the level of total antioxidant capacity, heat shock protein 70 (Hsp70), and defensin were selected for the analyses. In our opinion, the Hsp70 and defensin levels seemed to be important in the indication of urban multistress factors. The higher level of heat shock proteins and defensins in tissues/organs of bees from the urban apiary - in the gut (an increase, respectively, 92\% and 7.3\%) and fat body (an increase, respectively, 130\% and 7.8\%), known as targets of environmental toxins, pointed out the urban environment as highly stressful at both the individual and colony levels. In turn, high total antioxidant capacity was measured in the guts of honey bees from rural area (an increase 107\%). Such a situation suggests a different mechanism of defense and specificity of rural and urban environmental stressors and also honey bees foraging activity.
\end{abstract}

Keywords Biomarkers $\cdot$ Detoxification $\cdot$ Environmental stress $\cdot$ Enzyme activity $\cdot$ Honey bee $\cdot$ Laboratory tests $\cdot$ Urban beekeeping

\section{Introduction}

In recent years, there has been noted a decrease in the honey bee populations, especially in Europe (Potts et al. 2010) and North America (Ellis et al. 2010). In the USA, annual losses of bee colonies in 2011-2016 were estimated at as much as 50\% (van Engelsdorp et al. 2017). An increased intensification of

Responsible Editor: Ludek Blaha

Łukasz Nicewicz

lnicewicz@us.edu.pl

1 Research Team of Animal Physiology and Ecotoxicology, Faculty of Natural Sciences, Institute of Biology, Biotechnology and Environmental Protection, University of Silesia, Bankowa 9, 40-007 Katowice, PL, Poland agriculture, especially the use of plant protection chemicals and the loss of habitat diversity, has affected bees significantly, both at the individual and colony levels (van Engelsdorp and Meixner 2010; Johnson et al. 2010). Additionally, pesticides alter the susceptibility of bees to pathogens and may promote the spread of diseases (Pettis et al. 2012). However, the reasons for the decrease in honey bee populations may be multiple and can include not only unfavorable changes, diseases, and viruses, but also an insufficient quantity and quality of pollen due to the intensive agricultural practices (Maxim and Van Der Sluijs 2012). The loss of honey bee populations has caused an increase in the urban beekeeping interest, most notably in agglomerations (Lorenz and Kerstin 2015). Urban environments can be characterized by significantly lower use of pesticides, but also a higher content of heavy metals, air pollution, greater food base fragmentation, vehicle traffic, and more complicated spatial structures, which may all affect the 
welfare of bees (Cariveau and Winfree 2015; Negri et al. 2015; Rachael et al. 2009; Sadowska et al. 2019). All those environmental features are distinguished by a long term of acting on organisms on the NOAEL level and they are considered as a multistress (van Straalen 2003).

Despite the rapid development of urban beekeeping, there is scarce information about the condition of bees from beehives that are located in cities. There are several publications on the content of heavy metals in bees and in bee products such as honey or wax (Conti and Botrè 2001; Giglio et al. 2017; Lambert et al. 2012; Leita et al. 1996; Sadowska et al. 2019). The report of Lecocq and co-authors indirectly analyzed only the conditions of bees using their productivity, and therefore, there is still a need to know how the stress factors specific for urban environments may affect the welfare of bees (Lecocq et al. 2015).

Honey bee foragers are exposed to contaminants present in the air, water, soil, and vegetation that may be brought back to the hive and spread among the entire colony (Negri et al. 2015). The question is do an urban environment that is characterized by multiple urban stressors affect bees at both the individual and colony levels?

The chosen valuable stress exposure biomarkers are presented as sensitive to different environmental stressors, so the aim of the study was to compare biochemical endangerment in bees from the urban and rural apiary. To be specific, the biomarkers were measured in different tissues, among the others typical targets of environmental toxins, gut and fat body of the foragers, and in tissues which were connected with the exposure of toxins characterized high retention rate within the insects bodies, muscles or brain. It could be helpful in the assessment of specificity of urban and rural environmental pressure.

For this aim, well-known biomarkers were analyzed in various tissues of the bees: glutathione $S$-transferase (GST), acetylcholinesterase (AChE), total antioxidant capacity (TAC), heat shock protein 70 (Hsp70), and defensin level. GSTs are widely used as biomarkers of exposure to oxidative stress in invertebrates (Yan et al. 2013). The AChE activity may indicate that an animal was exposed to organophosphorus or carbamate insecticides (Nauen et al. 2001). GST and AChE response to insecticides was presented under exposure of four insecticides in individuals of A. mellifera (Badawy et al. 2015) and heavy metals (Nikolić et al. 2019). New data has indicated that AChE may be involved in the manifold stress response or stress management (Kim et al. 2017). TAC is another parameter measuring the almost complete antioxidative status of animals that are exposed to stress concerning their general "crude" antioxidant response level (Johnson and Carey 2014; Słowińska et al. 2016). Hsp70 is routinely used in ecosystem biomonitoring (Köhler et al. 1996). A high level of the Hsp70 indicates that an animal is under stress that exceeds the threshold for the damage to cells to be repaired and also affects the detoxification processes (Koban et al. 1991). Defensin is an antimicrobial peptide that is involved in the humoral immunity in honey bees together with apidaecin, abaecin, and hymenoptaecin. Its increased level may indicate animal life under stress factors that can reduce immunity (e.g., Antúnez et al. 2009; Casteels-Josson et al. 1994; Rand et al. 2015). Johnson (2015) emphasized "The honey bee colony is a nexus for all of the toxic compounds that exist in the environment" or that honeybees may be especially sensitive to certain insecticides and that their sensitiveness is moderated through many biotic or abiotic circumstances. The examination of the honey bees foraging in variably stressed environments as bioindicator is highly valuable, referring to, among the others, their immune or antioxidant response ( $\mathrm{Li}$ et al. 2018).

We hope that our results will be helpful in the achievement of better legitimacy for the introduction of beekeeping into cities.

\section{Material and methods}

\section{Honey bees}

All of the experiments were carried out on European-derived Carniolan forager bees (Apis mellifera carnica Pollman, 1879). The insects were collected from two apiaries located in urban and rural areas. These areas are described by the new degree classification of urbanization defined according to the population size, density, and contiguity of local administrative units level 2 (LAU2) by the European Commission (Dijkstra and Poelman 2014; Eurostat 2016). A conventional apiary is located in a rural area: $52^{\circ} 18^{\prime} 08.2^{\prime \prime} \mathrm{N}, 22^{\circ} 08^{\prime} 59.9^{\prime \prime} \mathrm{E}$, and urban apiary is located in the center of the city-Katowice: $50^{\circ} 15^{\prime} 51.0^{\prime \prime} \mathrm{N}, 19^{\circ} 01^{\prime} 12.3^{\prime \prime} \mathrm{E}$. The first apiary consists of 60 hives that are situated in a typical polish agricultural landscape and it is 20 years old. The urban apiary consists of five hives located on the rooftop of a 30-m high building in the center of Katowice city. This apiary has been run in this place for 3 years.

Even though both apiaries are located in different (south and north) parts of Poland, they are characterized by comparable weather condition components: temperature, atmospheric pressure, wind, humidity, precipitation, and cloudiness (average-year and chosen month data) (Table 1). Whereas, according to data obtained from two urban environmental pollution monitoring stations (the type of station, background level of pollution) located in Katowice and Siedlce $(30 \mathrm{~km}$ from rural apiary locality) indicated from 2 to 4 times higher concentration of suspended dust (PM10 and PM2.5) or measured heavy metals, arsenic, and benzo- $\alpha$-pyrene concentrations (Table 2). Katowice and the neighboring area are known as Silesia Agglomeration and it is recognized as a heavily contaminated place in Central Europe for years (Leśniok 
Table 1 Average year and June temperature and precipitation for each apiary localization in 2017. For the rural apiary, data was used for the nearest weather station in the city of Siedlce. Data source: World Meteorological Organization (WMO) (http://meteomanz.com/) and the Institute of Meteorology and Water Management-National Research Institute (http://meteomodel.pl)

\begin{tabular}{lllll}
\hline & \multicolumn{2}{l}{ Weather station } & \\
\cline { 2 - 5 } & Katowice & Siedlce & Katowice & Siedlce \\
\hline Period of measurement & 2017 -year & & 2017 -June \\
T $\left[{ }^{\circ} \mathrm{C}\right.$ ] & 9.2 & 8.6 & 18.3 & 17.4 \\
T. max ave. $\left[{ }^{\circ} \mathrm{C}\right]$ & 13.6 & 12.6 & 24.6 & 23.1 \\
T. min ave. $\left[{ }^{\circ} \mathrm{C}\right]$ & 4.8 & 4.7 & 12.0 & 11.6 \\
T, max abs. $\left[{ }^{\circ} \mathrm{C}\right]$ & 34.3 & 33.7 & 33.1 & 29.6 \\
T, min abs. $\left[{ }^{\circ} \mathrm{C}\right]$ & -26.0 & -21.5 & 5.7 & 5.7 \\
Prec. $[\mathrm{mm}]$ & 716.7 & 669.9 & 34.1 & 59.9 \\
Prec. days $0.1 \mathrm{~mm}$ & 178 & 171 & 12 & 12 \\
Days of storm & 31 & 31 & 4 & 7 \\
Days of frost & 94 & 80 & 0 & 0 \\
Days of snow & 57 & 60 & 0 & 0 \\
W. sp. $[\mathrm{km} / \mathrm{h}$ ] & 2.6 & 3.0 & 2.6 & 3.0 \\
Rel. h., ave. $[\%]$ & 76.5 & 79.8 & 62.2 & 68.6 \\
SLP [HPa] & 1017.4 & 1015.8 & 1014.2 & 1015.4 \\
Insolation $[\mathrm{h}]$ & 1713.0 & 1738.9 & 291.4 & 277.4 \\
Cloudy & 5.6 & 5.7 & 4.8 & 4.9 \\
\hline
\end{tabular}

$T$ temperature, $T$. max ave. average maximum temperature, $T$. min ave. average minimum temperature, $T$. $\max a b s$. absolute maximum temperature, T. min abs. absolute minimum temperature, Prec. precipitation, Prec. days $0.1 \mathrm{~mm}$ days of precipitation equal to or greater than 0.1 mm, W. $s p$. wind speed, Rel. $h$. air relative humidity, SLP sea level pressure, Insolation the total time (in hours) during that the sun rays fall directly on the Earth surface, Cloudy the degree of sky coverage by clouds on the octane scale $(0-8)$

2011), while the countryside of North-Eastern Poland is perceived as a "green lungs" of Europe (Szeszko 2017). The plants which are a potential food base for bees from both apiaries are growing in totally different circumstancespost-industrial and urban areas versus extensive agriculture areas.

Inseminated honey bee queens from both apiaries were genetically related - they came from the same line-breeding from the one Bee breeder ("Mellifera apiary"). The honey bee foragers were randomly collected in August 2017 from the entrance to the colony as they return from foraging (Scheiner et al. 2013). The collection of bees was carried out in all hives from the urban apiary and in five selected hives from the rural apiary. To minimalize the effect of the colony on obtained data, the colony strength (number of combs, queen age, number of comb with brood, honey, and pollen) of the five hives from the rural area was comparable to that of the honeybee colonies from the urban apiary. Insects were gathered to plastic vials (one bee per vial) and then transferred to liquid nitrogen. The animals were kept at $-70{ }^{\circ} \mathrm{C}$ until the sample preparation.

\section{Sample preparation}

Animals were kept on ice and their central nervous system (brain), fat body, thorax muscles, and gut were dissected at 4 ${ }^{\circ} \mathrm{C}$ according to Carreck et al. (2013). Brains for AChE activity analysis (one brain per sample) were homogenized in $50 \mu \mathrm{l}$ of $100 \mathrm{mM}$ phosphate-buffered saline (PBS; pH 7.4) (BioShop) with $0.5 \mu \mathrm{l}$ of Triton X-100 (BioRad). GST activity and TAC were measured in the brain, fat body, and gut homogenized in $20 \mu \mathrm{l}$ of PBS (pH 7.4). Similarly, the dissected brain, fat body, thorax muscle, and gut for the measurement of the Hsp70 and defensin level were homogenized in $20 \mu \mathrm{l}$ of 1 M PBS (pH 7.4). For these analysis, one brain, one gut, thorax muscle from one bee, and fat bodies from three bees per each sample were used.

Each tissue/organ obtained from bees from both the urban and the rural apiary constituted an experimental group. Tissues/organs of bees from rural apiary were considered as
Table 2 The suspended dust concentration (PM10 and PM2.5) and pollution level of selected pollutants in atmospheric particles for each apiary localization. Data for 2017. Data source: Chief Inspectorate of Environmental Protection in Poland n.d. (http:// www.gios.gov.pl/en/)

\begin{tabular}{|c|c|c|c|c|c|c|c|}
\hline \multirow[t]{2}{*}{ Index } & \multirow[t]{2}{*}{ Averaging time } & \multicolumn{3}{|l|}{ Katowice } & \multicolumn{3}{|l|}{ Siedlce* } \\
\hline & & Average & Min & Max & Average & Min & Max \\
\hline \multirow[t]{2}{*}{$\mathrm{PM} 10\left[\mu \mathrm{g} / \mathrm{m}^{3}\right]$} & $1 \mathrm{~h}$ & 41.643 & 3.949 & 671.591 & 29.038 & 4.006 & 360.277 \\
\hline & $24 \mathrm{~h}$ & 41.137 & 9.800 & 381.400 & 29.202 & 4.720 & 136.610 \\
\hline PM2.5 & $1 \mathrm{~h}$ & 32.551 & 3.530 & 512.891 & 22.981 & 2.980 & 328.689 \\
\hline$\left[\mu \mathrm{g} / \mathrm{m}^{3}\right]$ & & & & & & & \\
\hline $\mathrm{Pb}(\mathrm{PM} 10)\left[\mu \mathrm{g} / \mathrm{m}^{3}\right]$ & $24 \mathrm{~h}$ & 0.024 & 0.003 & 0.082 & 0.007 & 0.001 & 0.023 \\
\hline As (PM10) $\left[\mathrm{ng} / \mathrm{m}^{3}\right]$ & & 1.731 & 0.500 & 5.050 & 0.629 & 0.025 & 3.369 \\
\hline $\mathrm{Cd}(\mathrm{PM} 10)\left[\mathrm{ng} / \mathrm{m}^{3}\right]$ & & 0.993 & 0.100 & 9.270 & 0.241 & 0.025 & 0.705 \\
\hline $\mathrm{Ni}(\mathrm{PM} 10)\left[\mathrm{ng} / \mathrm{m}^{3}\right]$ & & 1.571 & 0.500 & 5.070 & 0.750 & 0.500 & 7.211 \\
\hline $\mathrm{BaP}$ (PM10) $\left[\mathrm{ng} / \mathrm{m}^{3}\right]$ & & 7.306 & 0.200 & 32.220 & 3.013 & 0.036 & 15.069 \\
\hline
\end{tabular}

*For the rural apiary, data was used for the nearest Regional Air Pollution Monitoring Station in Siedlce 
reference (control) groups. In total, eight test groups were distinguished. The experimental and control groups differed from one another in the tested parameters. The number of replicates for the given parameter in each experimental group was ten in two technical repetitions for each. Details about differences between these groups are presented in the Fig. 1.

All homogenates were centrifuged at $4{ }^{\circ} \mathrm{C}$ (for acetylocholine esterase (AChE) activity, $12092 \mathrm{~g}$ for $15 \mathrm{~min}$; glutathione transferase (GST) activity and total antioxidant capacity (TAC), $15000 \mathrm{~g}$ for $10 \mathrm{~min}$; Hsp70 and defensin level, $3000 \mathrm{~g}$ for $10 \mathrm{~min}$ ). The supernatants were decanted and the aliquots were kept in Eppendorf microtubes at - 70 ${ }^{\circ} \mathrm{C}$ until the measurements were performed.

The fresh mass of dissected tissues was determined on a laboratory analytical balance before homogenization. The measurements were performed to the scale reading uncertainty $\pm 0.0001 \mathrm{~g}$.

The total protein concentration in all of the samples was determined according to Bradford (1976).

\section{Stress biomarkers}

The acetylcholinesterase (AChE) activity was analyzed according to the modified method of Ellman et al. (1961) toward acetylcholine iodide as a substrate and expressed in $\mu$ moles of hydrolase acetylcholine iodide $\mathrm{min}^{-1} \mathrm{mg}^{-1}$ total protein.

The glutathione $S$-transferase (GST) activity was measured using a 15-mM ethanol solution of 1-chloro-2,4-dinitrobenzene
(CDNB) and expressed in $\mu$ moles of the GSH conjugates $\mathrm{min}^{-1} \mathrm{mg}^{-1}$ total protein ( $\mathrm{Yu}$ 1996).

The concentrations of heat shock protein 70 and defensin were measured using indirect ELISA, which was performed according to the standard protocol (Crowther 2009) and was optimized according to Pyza et al. (1997) and ChavezCrooker et al. (2003). Primary anti-Hsp antibody (Mouse Anti-Heat Shock Protein 70 monoclonal antibody, SigmaAldrich; 1:1000), anti-defensin antibody (Mouse Antidefensin monoclonal antibody, Abcam, 1:1000), and the goat anti-mouse IgG Polyclonal Antibody, AP-conjugate (Stressgen) were used. The concentration of Hsp70 was then expressed as the percentage [\%] of the total protein and defensin as the absorbance level at $405 \mathrm{~nm}$.

The total antioxidant capacity (TAC) was analyzed according to a modified method of Re et al. (1999) by Kafel et al. (2012). The result was expressed in terms of the equivalent anti-oxidant capacity to the Trolox and expressed as the $\mu \mathrm{mol}$ of the Trolox mg ${ }^{-1}$ protein based on a standard curve.

\section{Quality assurance and quality control}

In the research, we ensured the greatest possible accuracy and precision and the lowest possible uncertainty of the analyses and measurements performed. To reduce systematic uncertainty, (i) all measurements were made by the same researchers, (ii) all measurements (for tissues from bees collected from the urban and rural apiaries) were made at the same
Fig. 1 Details of the samples, their repetition, and marking in the study. The number of bees used to prepare one sample was different and depended on the size of the tissues/organs. A total of ten samples were prepared for each tissue/organ and the two technical replications were performed from each of them
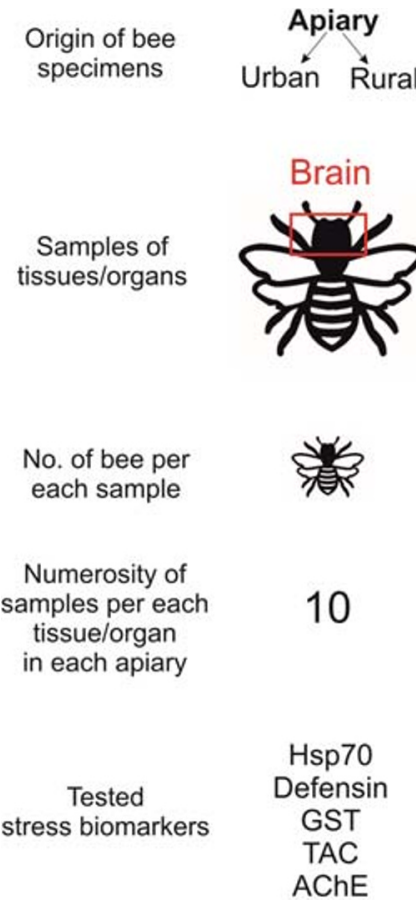

Note: two technical repetition of each measurements
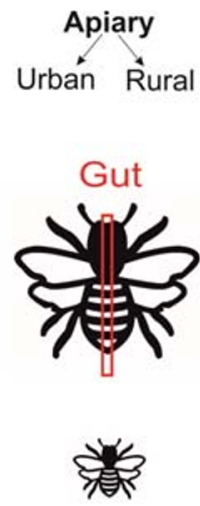

10

Hsp70
Defensin
GST
TAC

Hsp70

Defensin
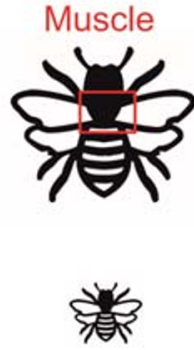

10

10
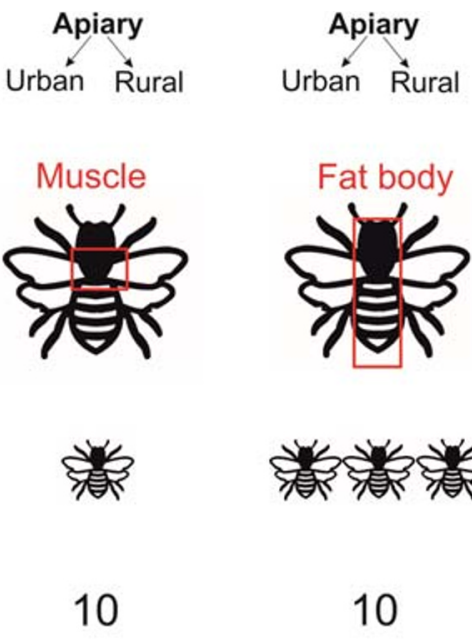

Urban Rural

(n)


time, and (iii) the measurements were started after calibration of the apparatus (if the calibration was possible). Random uncertainty was reduced by performing ten biological repetitions for each sample from tested tissue/organs and two technical repetitions for each sample. The method of sample preparation for each tissue/organ, the numbering of the samples, marking technical, and biological repetitions is presented in Fig. 1.

The uncertainties were quantified. All analyzed parameters were expressed as a mean value from technical and biological repetitions \pm average deviation. Scale reading uncertainty was also calculated for the using equipment: the laboratory balance $( \pm 0.0001)$ and the Tecan Infinite M200 Microplate reader $( \pm$ $0.0001)$.

Lack of positive controls for the tested biomarkers in honey bees (Hsp70 and defensin) or the chosen methodology of testing parameters (e.g., AChE and GST activity expressed as a continuous change in the absorbance) is the main problem. The standard curve was used to calculate concentration (total protein) and antioxidant capacity (TAC). The bovine serum albumin (BSA) series solution as a protein standard to the curve creation in the range of $0-1000 \mathrm{ug} / \mathrm{ml}$ was used. Series of the Trolox solutions in the range of 0-20 $\mu \mathrm{mol}$ was used to express the antioxidant capacity of tested tissues/organs. The linear calibration and the coefficient of determination $\left(\mathrm{r}^{2}\right)$ were analyzed. A value of $\mathrm{r}^{2}$ greater than 0.99 was considered satisfactory. The determination of Hsp70 and defensin levels were based on the total protein concentration based on the standard curve.

The precision of the measurements was analyzed on the basis of the results obtained for the technical repetitions of each sample.

\section{Statistical analyses}

All assays for the statistical analyses were based on ten samples, which were performed in duplicate. The results are reported as the mean values $\pm \mathrm{SD}$. Normality was checked using the Kolmogorov-Smirnov test. The significant differences were checked and the Student's $t$ test was used. Results with $p \leq 0.05$ were considered to be significant. The data were analyzed using GraphPad Prism® ver. 6.

\section{Results}

The fresh weight of the prepared tissues of central nervous systems, fat bodies, and guts of the honey bees from the urban and rural apiaries was comparable. However, the thorax muscle mass was statistically significantly higher in the bees from the rural apiary (2.5-fold) (Fig. 2).

A higher AChE activity in the honey bees' origin from rural apiary was statistically insignificant (Fig. 3a).
No variation in total antioxidant capacity was found, when compared results from the brain and gut tissues of honeybees from rural and urban areas. The statistically significant difference in the total antioxidant capacity was observed only in the case of the fat body. It was 2.36-fold higher in the fat body of honey bees from the rural apiary than in those from the urban apiary (Fig. 3c).

The Hsp70 level in the muscles of the thorax, fat bodies, and guts of the honey bees from the urban apiary was significantly higher $(2.85,2.3$, and 1.88 -fold, respectively) than in the bees that had been collected from the rural apiary. In turn, a similar level of Hsp70 proteins was presented in the case of honey bees' brain examination (Fig. 4a).

The defensin level was different in the fat body and gut of the honey bees tissues from tested apiaries and was 1.1-fold higher in the insects from the urban apiary. Brain and muscles of honey bees from both apiaries (rural and urban) did not vary (Fig. 4b).

\section{Discussion}

The localization of the apiary in Katowice was described as an urban area according to the definition of the European Commission (Dijkstra and Poelman 2014; Eurostat 2016). The urban area (alternative name, urban center) is characterized as a densely populated area (at least $50 \%$ population living in high-density clusters). Whereas, the rural apiary localization was defined as a thinly populated area (alternative name, rural area) where more than $50 \%$ of the population living in rural grid cells (Dijkstra and Poelman 2014). Urban environments are characterized by permanent higher exposure to potential multistress factors, such as the pollutions that are emitted by vehicle traffic, heating, and processing industries or burning of unappropriated fuels. Furthermore, the

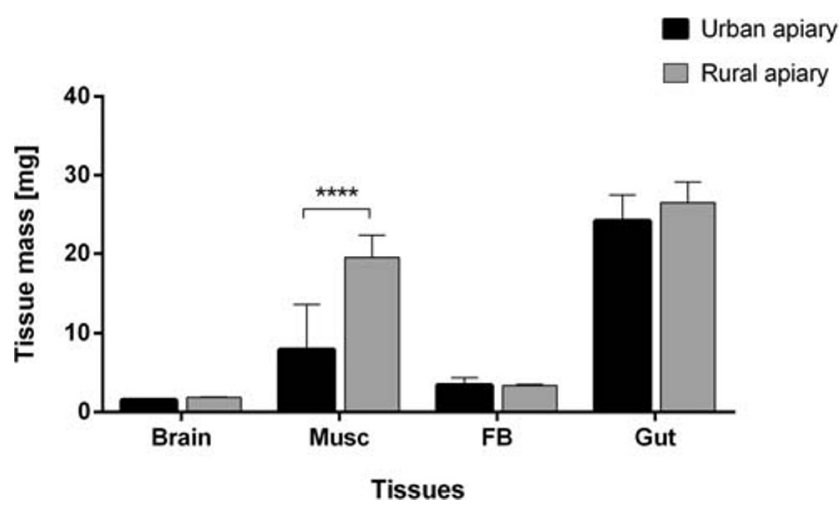

Fig. 2 Fresh tissue mass [mean $\pm \mathrm{SD}$ ] obtained from honey bee foragers. Tissue/organ masses are not statistically different in bees from the urban and rural apiary. Musc muscles from the thorax, FB fat body, Gut foregut, midgut, and hindgut. Asterisks indicate statistically significant differences between the same tissues in the bees from the urban and rural apiaries (Student's $t$ test, $p \leq 0.05$ ): **** $p \leq 0.0001 ; N=10$ 
phenomenon of heat islands, the spatial complexity of the center of cities, and the fragmentation of the food base can be observed in cities too (Lowenstein et al. 2014; Solecki et al. 2005). Therefore, the specificity of the stressors that act on the honey bees from urban apiaries (frequently on the NOEL level) compared to their situation in agricultural apiaries should be emphasized. The concentration of pesticides and heavy metals and organic compounds pollution were not measured in this research. However, the data obtained from GIOŚ for the apiary localization (Table 2) and literature data (Table 3) encourages to the comparative analysis of the level of environmental pressure on bees in these two different habitats. The rural apiary is situated in a typical polish agricultural landscape with low-area crops maize, rape or buckwheat, pesticide use (inefficient and excessive, Nowak and Bury 2017), and temporary lack of food. The urban apiary is located in the center of a medium city with heavy traffic (more than 110 thousand vehicles per day (GDDKiA 2020), on the rooftop of a 30-m high building. Therefore, bees are potentially exposed to different types of chemical pollutants from vehicles, higher temperatures because of the sun heated up the roof, and the presence of stronger air currents between buildings. Besides, bees use as a food base located in areas contaminated with many organic and inorganic pollutants. A summary of the general possible differences between urban and rural environment and general features of apiaries located in these areas based on the literature are presented, respectively, in Table 3 and Table 4.

Our results revealed that the activity of GST and AChE did not differ significantly when taken into consideration any examined tissues in the bees from the urban and rural apiaries. It seems to be surprising these two parameters are important
Fig. 3 The activity of acetylcholinesterase (AChE) and glutathione $S$-transferase (GST) as well as the level of total antioxidant capacity (TAC) index in examined tissues of honey bee foragers. a AChE activity [mean $\pm \mathrm{SD}$ ], b GST activity [mean \pm $\mathrm{SD}]$, and $\mathbf{c} \mathrm{TAC}[$ mean $\pm \mathrm{SD}]$ are not an appropriate biomarker of exposure to the stress of bees. Musc muscles from the thorax, FB fat body, Gut foregut, midgut, and hindgut. Asterisks indicate statistically significant differences between the same tissues in the bees from the urban and rural apiaries (Student's $t$ test, $p \leq 0.05): * * p \leq 0.01 ; N=10$ a

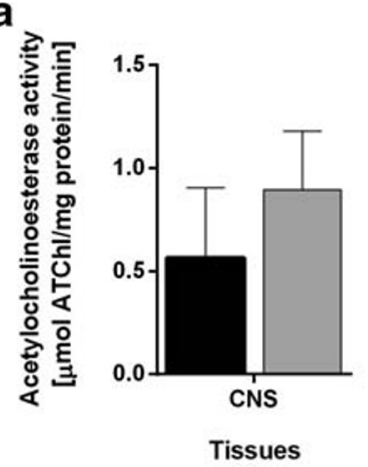

b

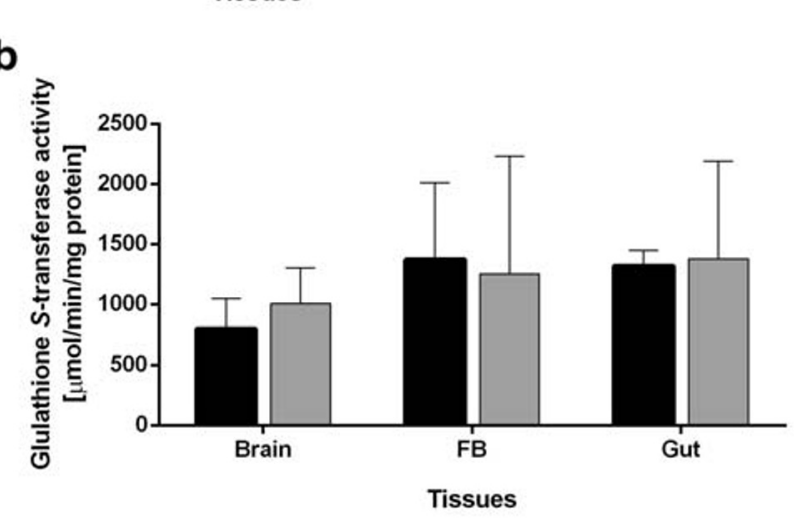

C

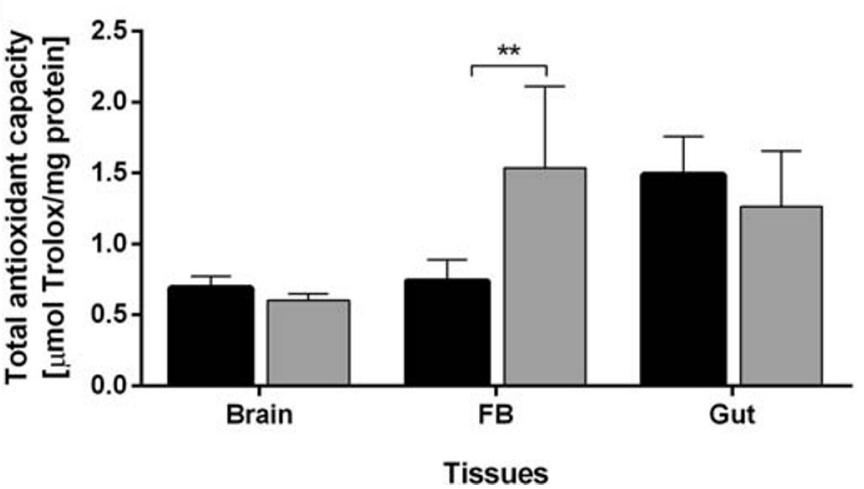

Tissues
Urban apiary

Rural apiary 
Fig. 4 The heat shock protein 70 (Hsp70) and defensin levels in the examined tissues of the honey bee foragers. a Hsp70 as a percentage of total protein $[$ mean $\pm \mathrm{SD}]$ and $\mathbf{b}$ defensin levels as the absorbance $[$ mean $\pm \mathrm{SD}]$ seem to be important in the indication of urban multistress factors. brain, Musc muscles from the thorax, FB fat body, Gut foregut, midgut, and hindgut. Asterisks indicate statistically significant differences between the same tissues in the bees from the urban and rural apiaries (Student's $t$ test, $p \leq 0.05$ ): **** $p$ $\leq 0.0001 ; N=10$

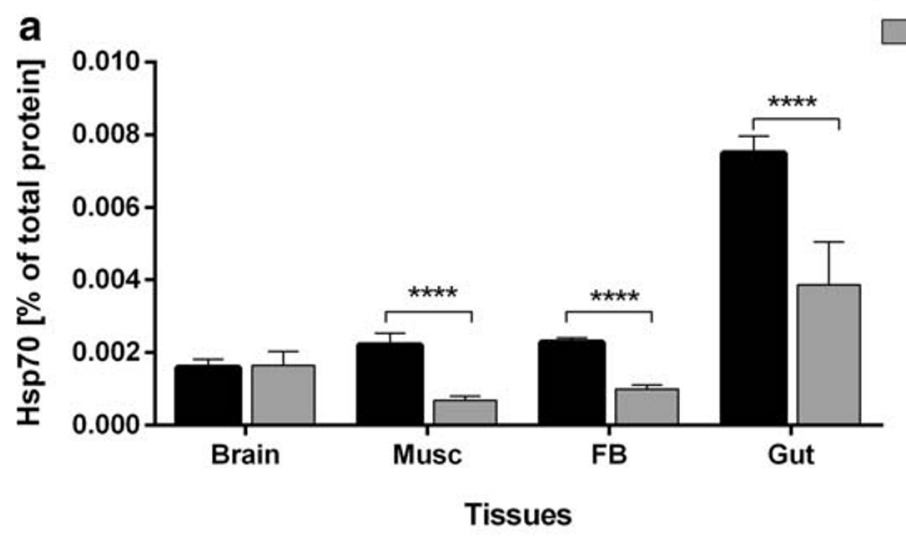

Urban apiary

Rural apiary

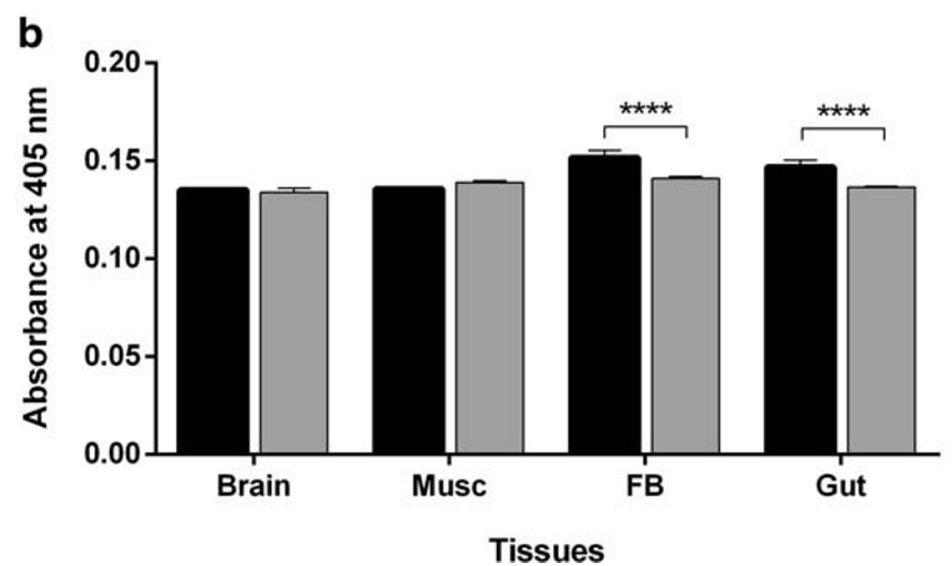

components of the stress response in invertebrates (e.g., Yan et al. 2013), and were proposed as a promising tool in the evaluation of honeybee health (e.g., Carvalho et al. 2013). Especially, changes in the AChE activities are presented as sensitive responses to pesticides that are widely used in agriculture also in the tested rural area (e.g., Nauen et al. 2001). Our results may indicate that bees from both apiaries were not seriously affected by pesticides, at least those from the neonicotinoid group. All the more so because artificial feeding of honey bees workers with different concentrations
Table 3 Several examples of important characteristics of urban environments referring to various aspects of environmental pollution and the degree of urbanization

\begin{tabular}{|c|c|}
\hline Dominant features of urban areas compared to the rural areas & References \\
\hline $\begin{array}{l}\text { Higher population density, larger settlement size, higher patchiness } \\
\text { and variation of landscapes, higher environmental burdens from } \\
\text { fuel combustion, waste processing, water consumption } \\
\text { (acid deposition, oxides emissions, waste and sewage production). } \\
\text { Lower agricultural occupational profile. }\end{array}$ & McGranahan 2005 \\
\hline $\begin{array}{l}\text { Higher total } \mathrm{Cd}, \mathrm{Cu}, \mathrm{Ni}, \mathrm{Pb} \text { and } \mathrm{Zn} \text { concentration in soil } \\
\text { (Aberdeen, United Kingdom). }\end{array}$ & Yang et al. 2006 \\
\hline $\begin{array}{l}\text { Higher numbers of ozone days, the total number of days with fine } \\
\text { particulate matter (PM 2.5), the better quality of the water quality (USA). }\end{array}$ & Strosnider et al. 2017 \\
\hline $\begin{array}{l}\text { Higher level of nitrogen dioxide and sulfur dioxide } \\
\text { (Maroussi municipality, Greece). }\end{array}$ & Priftis et al. 2007 \\
\hline $\begin{array}{l}\text { Higher level of } \mathrm{Cd}, \mathrm{Cu}, \mathrm{Hg}, \mathrm{Pb} \text { and } \mathrm{Zn} \text {, which mainly derived from } \\
\text { anthropogenic inputs (Wuhan, China). }\end{array}$ & Gong et al. 2010 \\
\hline $\begin{array}{l}\text { Higher level of local human wastes in the water, the domination } \\
\text { of combustion fuel pollutants and specific to local production } \\
\text { pollutants, more industries, more semi-natural landscapes like } \\
\text { gardens, cemeteries, parklands (Hanoi, Vietnam; Los Angeles, USA). }\end{array}$ & McGranahan et al. 2004 \\
\hline Higher $\mathrm{Pb}, \mathrm{Zn}, \mathrm{Cr}, \mathrm{Ni}, \mathrm{Sn}, \mathrm{Cu}, \mathrm{Mo}$, An concentration (Teresina, Brasil). & Mancarella et al. 2017 \\
\hline
\end{tabular}


of $\mathrm{Cd}, \mathrm{Pb}$, and $\mathrm{Cu}$ in sucrose solutions changed GST and $\mathrm{AChE}$ activity and increased level of gene expression of the three classes of GST with increasing concentrations of $\mathrm{Cu}$ and Cd (Nikolić et al. 2019).

Analysis of the TAC revealed that the fat body was the only tissue that shows apiary localization-dependent differences. The higher TAC in the fat body of bees from the rural apiary was observed. There may be a need to elevate antioxidant protection against oxidative stress in bees from this localization. The varied prooxidant action of ingested food can be the possible source of differences in the antioxidant capacity between bees from the city and rural areas (Chainy et al. 2016; Słowińska et al. 2016). For example, the pollen and nectar that are collected by bees may differ in the content polyphenols and flavonoids, and thus the antioxidant capabilities (Aličić et al. 2014).

Our study revealed that foragers from the urban apiary differ in the level of the Hsp70 and defensins compared to the bees from the rural apiary. Besides, these responses are tissue-specific. These biomarkers indicate on processes of protection against stress factors among the others chaperone system toward proteins (Fink 1999; Kregel 2012; Saibil 2013) and activation of the immune system (Antúnez et al. 2009; Casteels-Josson et al. 1994).
The Hsp70 level was significantly higher in the thorax muscles, fat body, and gut of the foragers from the urban apiary than in the insects from the rural apiary. Hsps play the role of molecular chaperons of cells stabilizing proteins and inhibiting apoptosis. Their synthesis can also be induced by changes in ambient temperature as well as by toxins such as pesticides or metals (Fink 1999; Kregel 2012). So, enhancement of these proteins level may be connected with different reasons: a higher need to stabilize proteins in highly stressful conditions of surrounding urban apiary or may be connected with higher foraging activity.

The oxidative and mechanical damage that is induced by the intense work of the thorax muscles and the high temperatures that are generated by this work may be the primary reasons for the increased level of Hsp70 in this tissue. The strong heterothermia within individual foragers that had a thoracic temperature in a much higher level than normal (approximately $40{ }^{\circ} \mathrm{C}$ and higher) and the head temperature (10 to 14 ${ }^{\circ} \mathrm{C}$ ) could be because the Hsp70 expression reduces any heatinduced damage (Elekonich 2009; Roberts and Harrison 1999). Furthermore, the location of the apiary on the rooftop of a high building (about $30 \mathrm{~m}$ ) and the fragmentation of the food base could also be the main reasons for the intense muscle work (and consequently, cell-damage of its) in the bees from the urban apiary. It should be noted that a high level of

Table 4 Urban vs rural area - apiary features based on selected relevant literature (the most important)

\begin{tabular}{|c|c|}
\hline Dominant features of apiaries & References \\
\hline \multicolumn{2}{|l|}{ Urban areas } \\
\hline $\begin{array}{l}\text { Higher level of the contaminants in pollen, especially } \mathrm{Al}, \mathrm{Cd}, \mathrm{Pb} \text {, and Co during July-October } \\
\text { (southern-eastern Brasil). }\end{array}$ & Morgano et al. 2010 \\
\hline $\begin{array}{l}\text { Indication of the markers of honey bees contamination: } \mathrm{Al}, \mathrm{As} \text {, and } \mathrm{Cr} \text { on the bee body surface and } \\
\mathrm{Cd} \text { inside bodies. Slightly higher levels of } \mathrm{As}, \mathrm{Al}, \mathrm{Pb} \text {, and } \mathrm{Cd} \text { in bees (Warsaw, Poland). }\end{array}$ & Sadowska et al. 2019 \\
\hline Higher amounts of total phenols in honey (across Ireland) & Kavanagh et al. 2019 \\
\hline $\begin{array}{l}\text { Metal }(\mathrm{Pb}, \mathrm{Cd}, \mathrm{Cu}, \mathrm{Fe}, \mathrm{Zn}, \mathrm{Mn}, \mathrm{Ni}, \mathrm{Cr}, \mathrm{Hg}) \text {, PAHs concentration in honey bee and pollen is } \\
\text { within the regulatory level (Belgrade and vicinity, Serbia). }\end{array}$ & Jovetic et al. 2018 \\
\hline $\begin{array}{l}\text { Higher deposits of particles }\left(\mathrm{NO}_{3}^{-}, \mathrm{SO}_{4}{ }^{2-}, \mathrm{NH}^{+}\right) \text {and gaseous pollutants }\left(\mathrm{NO}_{2}, \mathrm{SO}_{2} \text { and } \mathrm{NH}_{3}\right) \text { and } \\
\text { concentration of } \mathrm{Al}, \mathrm{Fe} \text {, Ti in pollen grains (Saitama, Japan). }\end{array}$ & Wang et al. 2009 \\
\hline Higher amounts of $\mathrm{Pb}, \mathrm{Cr}, \mathrm{Cd}$ in honeybee foragers (Abruzzi and Latium regions, Italy). & Perugini et al. 2011 \\
\hline $\begin{array}{l}\text { More frequently measured the part of PAHs in honey bees registered during one year ( } 5 \text { of 20ies). } \\
\text { 3-ringed substances were present often and more in autumnal than summer samples } \\
\text { (14 departments, France). }\end{array}$ & Cochard et al. 2020 \\
\hline \multicolumn{2}{|l|}{ Rural areas } \\
\hline $\begin{array}{l}\text { Around } 31 \text { substances, the main rests were found in the case of amitraz, coumaphos, acrinathrin, } \\
\text { cypermethrin, tau-fluvalinate as an effect of veterinary treatment and crop-contamination inside } \\
\text { the hives (mainly beeswax or bee brood) (Córdoba, South Spain). }\end{array}$ & Morales et al. 2020 \\
\hline Higher level chlorpyriphos and acetamiprid in apiaries (across Spain). & Calatayud-Vernich et al. 2018 \\
\hline $\begin{array}{l}\text { Contamination of honey with metals }(\mathrm{Cd}, \mathrm{Mn}, \mathrm{Cu}) \text { in dependence on local conditions and the } \\
\text { use of pesticides or fertilizers in Umbria ( } 35 \text { cites, Italy) }\end{array}$ & Goretti et al. 2020 \\
\hline Higher risk of neonicotinoids and fungicides (UK). & David et al. 2016 \\
\hline Less number of microbial spores in honey (Belgrade and vicinity, Serbia). & Matović et al. 2018 \\
\hline $\begin{array}{l}\text { Higher pesticides concentrations and more often detected presence in bumblebees from rural } \\
\text { areas than from more urban areas (East Sussex, UK) }\end{array}$ & Botias et al. 2017 \\
\hline
\end{tabular}


Hsp70 may also be a manifestation of thermal tolerance in the thoracic muscles of the foragers from the urban apiary (Elekonich 2009).

The fat body of insects is the most metabolically active tissues and plays a crucial role in storing and utilizing energy and in detoxification processes. It is responsible for the synthesis of most of the hemolymph proteins (Arrese and Soulages 2010). The higher level of Hsp70 in the fat body of the foragers from the urban apiary might indicate a higher exposure of bees from the city to stress, but may also be a more appropriate response to any stress factors.

The gut is an organ that has direct contact with contaminated food, and thus as a target for various chemicals, it is extremely important from an ecotoxicological point of view as well as for insect studies (Malaspina and Mathias da SilvaZacarin 2006). Numerous analyses have indicated that pollen can be contaminated with heavy metals (Conti and Botrè 2001; Lambert et al. 2012) or pesticides, even if it comes from wild plants (Long and Krupke 2016). Jabłoński et al. (1995) showed that there were almost three times more lead and six times more cadmium in the pollen than in the honey and in the nectar that had been collected directly from plants. These data indicate that foragers may be exposed to contaminants in high doses and over a long period of time. Our results revealed that the gut was the organ that had the highest Hsp70 level in the foragers from both the urban and rural apiaries. This may indicate that the guts of foragers from both apiaries could be the main route of xenobiotics action, and it seems the urban environment may be a bigger challenge in this case (e.g., connected with the pollution of nectar pollutants) than the rural environment because the Hsp70 level was higher in the guts of honey bees from the urban apiary.

The brain was the only organ in which no differences in the Hsp70 level were found. Similar results were reported by Elekonich (2009). It seems that the efficient defense mechanisms that protect the brain in other animals are an ancient evolutionary mechanism (Fink 1999) and it may also exist in honey bees. Protective role of transport barrier in the case of the central nervous system is valid in brain protection (Hindle et al. 2017). Moreover, it is possible important mechanisms of specific chemical defense, for example with cytochrome P450 system against neonicotinoid insecticides (Manjon et al. 2018).

The defensin level was slightly higher in the fat body and gut of the foragers from the urban apiary compared to the bees from the rural apiary. The fat body is the main site of the synthesis of the antimicrobial proteins that are synthesized under an injury and inductors (e.g., bacteria, fungi, and some insecticides) that may be present in the hemolymph (Ilyasov et al. 2012). The higher level of defensin in both the fat body and gut could indicate a possibility of existing of an infection in the foragers from the urban apiary. However, no symptoms of any disease were found. Moreover, the literature data indicate that the defensin level may be decreased by Nosema and Varroa destructor infection (Chaimanee et al. 2012). Furthermore, the Lactobacillus, which is non-pathogenic bacteria to bees, can stimulate the expression of defensin (Ilyasov et al. 2012).

To sum up, the increased level of the Hsp70 and defensins levels may mean that bees from the urban apiary are under greater pressure from stress factors in the city than in the rural area. This could mean that the multiple urban stressors may affect bees at both the individual and colony levels.

In our opinion, among selected biomarkers of urban honey bees' multistress analysis, the most promising seems to be heat shock proteins and defensin, and secondly total antioxidant capacity. The most appropriate tissue for these investigations seems to be a fat body where the diverse answer for environmental conditions was observed at a statistically significant level. In addition, furthermore specific examinations are needed to show the main urban stressors which may pose a threat for honey bees' populations in these promising apiary areas.

It would seem that the bees from the apiary located on the roof should have a greater muscle mass, which would enable them to fly to and from the apiary effectively. However, our results indicate that the mass of the muscles of the foragers from the urban apiary was significantly lower than the muscles of the foragers from the rural area. It is possible that, despite the difficult location of the hive and the fragmentation of the food base, the bees from the city do not have to fly over large distances like bees from rural areas. It is also possible that these foragers find food in close proximity to the apiary (e.g., in the parks inside the city or in flower beds) and that the warm air currents enable them to reach the roofs of buildings, and therefore, a high muscle mass is not necessary. However, Correa-Fernandez and Cruz-Landim (2010) revealed that the flight muscles from foraging workers might be resorbed and used as a supplementary source of energy. The reduction in thorax mass in flying insects is common, e.g., in nectarfeeding butterflies, but without affecting the flight performance negatively (Stjernholm et al. 2005). The reduction of muscle mass in bee foragers can be possible by damage due to flight wear down (Fernandez-Winckler and Cruz-Landim 2008). The high level of apoptosis-inhibiting proteins Hsp70 that was observed in our study in the thorax muscles in bees from the urban apiary can confirm these observations.

\section{Conclusions}

Our study revealed that the multiple urban stressors may affect bees at both the individual and colony levels. In details, the level of two biomarkers of stress exposure (Hsp70 and defensins) differs among honey bee foragers from the urban and rural apiary. In addition, it seems that that the Hsp70 and 
the defensin levels and not the activity of GST and AChE are applicable biomarkers of stress exposure of the honey bees from apiaries that are located in the center of cities. To sum up, the welfare of honey bees from urban apiaries requires attention and more advanced further research.

Our conclusions from these studies are in contrast to those that were obtained by Badiou-Bénéteau et al. (2012, 2013) and Yan et al. (2013). However, it should be noted that they did not investigate bees from urban apiaries.

In light of the results that were obtained in this study, we begin work on creating a new experimental model. It consists of two professional apiaries (one located on the urban rooftop of the University building in Katowice, the center of the Silesian agglomeration and the other in rural areas- $100 \mathrm{~km}$ from the center of the agglomeration) with genetically related honey bee colonies. In our opinion, such an experimental model will enable a much more reliable comparison between the welfare of honey bees from urban and rural apiaries and it will give the unusual possibility to compare various biological parameters of these colonies at different levels of their biological organization.

Acknowledgments We thank "Pszczelarium" company and Łukasz Przybył for making the urban apiary available and Marta Sawadro for her assistance in collecting the samples. We would also like to thank Michele Simmons, native speaker of English, who proofread the manuscript.

Authors' contributions $\mathrm{N}$ and $\mathrm{AN}$ conceived this research, designed experiments, and performed them; All authors participated in the interpretation of the data; All authors wrote the paper and participated in the revisions of it. All authors read and approved the final manuscript.

Data availability The datasets used and/or analyzed during the current study are available from the corresponding author on reasonable request.

\section{Compliance with ethical standards}

Ethics approval and consent to participate Not applicable.

Consent for publication Not applicable.

Competing interests The authors declare that they have no competing interests.

Open Access This article is licensed under a Creative Commons Attribution 4.0 International License, which permits use, sharing, adaptation, distribution and reproduction in any medium or format, as long as you give appropriate credit to the original author(s) and the source, provide a link to the Creative Commons licence, and indicate if changes were made. The images or other third party material in this article are included in the article's Creative Commons licence, unless indicated otherwise in a credit line to the material. If material is not included in the article's Creative Commons licence and your intended use is not permitted by statutory regulation or exceeds the permitted use, you will need to obtain permission directly from the copyright holder. To view a copy of this licence, visit http://creativecommons.org/licenses/by/4.0/.

\section{References}

Aličić D, Šubarić D, Jašić M, Pašalić H, Ačkar D (2014) Antioxidant properties of pollen. Hrana u Zdr i Boles Znan časopis za Nutr i dijetetiku 3:6-12

Antúnez K, Martín-Hernández R, Prieto L, Meana A, Zunino P, Higes M (2009) Immune suppression in the honey bee (Apis mellifera) following infection by Nosema ceranae (Microsporidia). Environ Microbiol 11:2284-2290. https://doi.org/10.1111/j.1462-2920. 2009.01953.x

Arrese EL, Soulages JL (2010) Insect fat body: energy, metabolism, and regulation. Annu Rev Entomol 55:207-225. https://doi.org/10. 1146/annurev-ento-112408-085356.INSECT

Badawy MEI, Nasr HM, Rabea EI (2015) Toxicity and biochemical changes in the honey bee Apis mellifera exposed to four insecticides under laboratory conditions. Apidologie 46:177-193. https://doi. org/10.1007/s13592-014-0315-0

Badiou-Bénéteau A, Carvalho SM, Brunet JL, Carvalho GA, Buleté A, Giroud B, Belzunces LP (2012) Development of biomarkers of exposure to xenobiotics in the honey bee Apis mellifera: application to the systemic insecticide thiamethoxam. Ecotoxicol Environ Saf 82: 22-23. https://doi.org/10.1016/j.ecoenv.2012.05.005

Badiou-Bénéteau A, Benneveau A, Géret F, Delatte H, Becker N, Brunet JL, Reynaud B, Belzunces LP (2013) Honeybee biomarkers as promising tools to monitor environmental quality. Environ Int 60: 31-41. https://doi.org/10.1016/j.envint.2013.07.002

Botias C, David A, Hill E, Goulson D (2017) Quantifying exposure of wild bumblebees to mixtures of agrochemicals in agricultural and urban landscapes. Environ Pollut 22:73-82. https://doi.org/10.1016/ j.envpol.2017.01.001

Bradford M (1976) A rapid and sensitive method for the quantitation of microgram quantities of protein utilizing the principle of protein-dye binding. Anal Biochem 72:248-254. https://doi.org/10.1016/00032697(76)90527-3

Calatayud-Vernich P, Calatayud F, Simo E, Pico Y (2018) Pesticide residues in honey bees, pollen and beeswax: assessing beehive exposure. Environ Pollut 241:106-114. https://doi.org/10.1016/j. envpol.2018.05.062

Cariveau DP, Winfree R (2015) Causes of variation in wild bee responses to anthropogenic drivers. Curr Opin Insect Sci 10:104-109. https:// doi.org/10.1016/j.cois.2015.05.004

Carreck NL, Andree M, Brent CS, Cos-Foster D, Dade AH, Ellis JD, Hatijna F, van Englesdorp D (2013) Standard methods for Apis mellifera anatomy and dissection. J Apic Res 52:1-40. https://doi. org/10.3896/IBRA.1.52.4.03

Carvalho SM, Belzunces LP, Carvalho GA, Brunet JL, Badiou-Beneteau A (2013) Enzymatic biomarkers as tools to assess environmental quality: a case study of exposure of the honeybee Apis mellifera to insecticides. Environ Toxicol Chem 32:2117-2124. https://doi.org/ $10.1002 /$ etc. 2288

Casteels-Josson K, Zhang W, Capaci T, Casteels P, Tempst P (1994) Acute transcriptional response of the honeybee peptide-antibiotics gene repertoire and required post-translational conversion of the precursor structures. J Biol Chem 269:28569-28575

Chaimanee V, Chantawannakul P, Chen Y, Evans JD, Pettis JS (2012) Differential expression of immune genes of adult honey bee (Apis mellifera) after inoculated by Nosema ceranae. J Insect Physiol 58: 1090-1095. https://doi.org/10.1016/j.jinsphys.2012.04.016

Chainy GBN, Paital B, Dandapat J (2016) An overview of seasonal changes in oxidative stress and antioxidant defense parameters in some invertebrate and vertebrate species. Scientifica (Cairo) UNSP 6126570. https://doi.org/10.1155/2016/6126570

Chavez-Crooker P, Pozo P, Castro H, Dice MS, Boutet I, Tanguy A, Moraga D, Ahearn GA (2003) Cellular localization of calcium, heavy metals, and metallothionein in lobster (Homarus americanus) 
hepatopancreas. Comp Biochem Physiol Part C Toxicol Pharmacol 136:213-224. https://doi.org/10.1016/S1532-0456(03)00213-8

Chief Inspectorate of Environmental Protection in Poland. http://www. gios.gov.pl/en/. Accessed 20 April 2020

Cochard P, Laurie M, Veyrand B, Le Bizec B, Poirot B, Marchand P (2020) PAH7 concentration reflects anthropization: A study using environmental biomonitoring with honeybees. Sci Total Environ 751:141831. https://doi.org/10.1016/j.scitotenv.2020.141831

Conti ME, Botrè F (2001) Honeybees and their products as potential bioindicators of heavy metals contamination. Environ Monit Assess 69:267-282. https://doi.org/10.1023/A:1010719107006

Correa-Fernandez F, Cruz-Landim C (2010) Differential flight muscle development in workers, queens and males of the eusocial bees, Apis mellifera and Scaptotrigona postica. J Insect Sci 10:85-89. https://doi.org/10.1673/031.010.8501

Crowther JR (2009) The ELISA guidebook, 2nd edn. Springer-Verlag $\mathrm{GmBH}$, New Jersey

David A, Botias C, Abdul-Sada A, Nichols E, Rotheray E, Hill E, Goulson D (2016) Widespread contamination of wildflower and bee-collected pollen with complex mixtures of neonicotinoids and fungicides commonly applied to crops. Environ Int 88:169-178. https://doi.org/10.1016/j.envint.2015.12.011

Dijkstra L, Poelman A (2014) A harmonized definition of cities and rural areas: the new degree of urbanization. Regional Working Paper 2014. The Directorate-General for Regional and Urban Policy, WP 01/2014. European Commission. pp: 28

Elekonich MM (2009) Extreme thermotolerance and behavioral induction of $70-\mathrm{kDa}$ heat shock proteins and their encoding genes in honey bees. Cell Stress Chaperones 14:219-226. https://doi.org/ 10.1007/s12192-008-0063-z

Ellis JD, Evans JD, Pettis J (2010) Colony losses, managed colony population decline, and colony collapse disorder in the United States. J Apic Res 49:134-136. https://doi.org/10.3896/IBRA.1.49.1.30

Ellman GL, Courtney KD, Andres VF-SR (1961) A new and rapid colorimetric determination of acetylcholinesterase activity. Biochem Pharmacol 7:88-95. https://doi.org/10.1016/0006-2952(61)90145-9

Eurostat (2016) Degree of urbanisation (DEGURBA). Source: https://ec. europa.eu/eurostat/web/degree-of-urbanisation/background. Accessed 20 Oct 2020

Fernandez-Winckler F, Cruz-Landim C (2008) A morphological view of the relationship between indirect flight muscle maturation and the flying needs of two species of advanced eusocial bees. Micron 39: $1235-1242$

Fink AI (1999) Chaperone-mediated protein folding. Physiol Rev 79: 425-449. https://doi.org/10.1152/physrev.1999.79.2.425

GDDKiA (2020) General Directorate for National Roads and Motorways. https://www.gddkia.gov.pl/ (in Polish)

Giglio A, Ammendola A, Battistella S, Naccarato A, Pallavicini A, Simeon E, Tagarelli A, Giulianini G (2017) Apis mellifera ligustica, Spinola 1806 as bioindicator for detecting environmental contamination: a preliminary study of heavy metal pollution in Trieste, Italy. Environ Sci Pollut Res 24:659-665. https://doi.org/10.1007/ s11356-016-7862-z

Gong M, Wu L, Bi XY, Ren LM, Wang L, Ma ZD, Bao ZY, Li ZG (2010) Assessing heavy-metal contamination and sources by GISbased approach and multivariate analysis of urban-rural topsoils in Wuhan, central China. Environ Geochem Health 32(1):59-72. https://doi.org/10.1007/s10653-009-9265-2

Goretti E, Pallotini M, Rossi R, La Porta G, Gardi T, Cenci Gog B, Elia A, Galletti M, Moroni B, Petroselli C, Selvaggi R, Capelletti D (2020) Heavy metal bioaccumulation in honey bee matrix, an indicator to assess the contamination level in terrestrial environments. Environ Pollut 256:113388. https://doi.org/10.1016/j.envpol.2019. 113388

Hindle SJ, Munji RN, Dolghih E, Gaskins G, Orng S, Ishimoto H, Soung A, DeSalvo M, Kitamoto T, Keiser MJ, Jacobson MP, Daneman R,
Bainton RJ (2017) Evolutionarily conserved roles for blood-brain barrier xenobiotic transporters in endogenous steroid partitioning and behavior. Cell Rep 21:1304-1316. https://doi.org/10.1016/j. celrep.2017.10.026

Ilyasov R, Gaifullina L, Saltykova E, Poskryakov A, Nikolenko A (2012) Review of the expression of antimicrobial peptide defensin in honey bees Apis mellifera. J Apicult Sci 56:115-124. https://doi.org/10. 2478/v10289-012-0013-y

Jabłoński B, Kołtowski Z, Marcinkowski J, Rybak-Chmielewksa H, Szczesna $\mathrm{T}$ (1995) Content of heavy metals $(\mathrm{Pb}, \mathrm{Cd}$ and $\mathrm{Cu})$ in nectar, honey and pollen from plants growing along communication routes. Pszczel Zesz Nauk 2:129-144 (in Polish)

Johnson RM (2015) Honey bee toxicology. Annu Rev Entomol 60:415434

Johnson B, Carey JR (2014) Hierarchy and connectedness as determinants of health and longevity in social insects. Sociality, hierarchy, health: comparative biodemography: a collection of papers. 269293. https://doi.org/10.17226/18822

Johnson RM, Ellis MD, Mullin CA, Frazier M (2010) Pesticides and honey bee toxicity-USA. Apidologie 41:312-331. https://doi.org/ 10.1051/apido/2010018

Jovetic M, Redzepovic A, Nedic N, Vojt D, Durdic S, Brceski I, Milojkovic-Opsenica D (2018) Urban honey-the aspects of its safety. Arh Hig Rada Toksikol 69:264-274. https://doi.org/10. 2478/aiht-2018-69-3126

Kafel A, Zawisza-Raszka A, Szulińska E (2012) Effects of multigenerattional cadmium exposure of insects (Spodoptera exigua larvae) on anti-oxidant response in hemolymph and developmental parameters. Environ Pollut 162:8-14. https://doi.org/10.1016/j. envpol.2011.09.034

Kavanagh S, Gunnoo J, Passos T, Stout J, White B (2019) Physicochemical properties and phenolic content of honey from different floral origins and from rural versus urban landscapes. Food Chem 272:66-75. https://doi.org/10.1016/j.foodchem.2018. 08.035

Kim YH, Kim JH, Kim K, Lee SH (2017) Expression of acetylcholinesterase 1 is associated with brood rearing status in the honey bee, Apis mellifera. Sci Rep 7:1-8. https://doi.org/10.1038/srep39864

Koban M, Yup AA, Agellon LB, Powers DA (1991) Molecular adaptation to environmental temperature: heat-shock response of the eurythermal teleost Fundulus heteroclitus. Mol Mar Biol Biotechnol 1: $1-17$

Köhler HR, Rahman B, Gräff S, Berkus M, Triebskorn R (1996) Expression of the stress-70 protein family (hsp70) due to heavy metal contamination in the slug, Deroceras reticulatum: an approach to monitor sublethal stress conditions. Chemosphere 33: 1327-1340. https://doi.org/10.1016/0045-6535(96)00270-6

Kregel KC (2012) Heat shock proteins: modifying factors in physiological stress responses and acquired thermotolerance. J Appl Physiol 92:2177-2186. https://doi.org/10.1152/japplphysiol.01267.2001

Lambert O, Piroux M, Puyo S, Thorin C, Larhantec M, Delbac F, Pouliquen H (2012) Bees, honey and pollen as sentinels for lead environmental contamination. Environ Pollut 170:254-259. https://doi.org/10.1016/j.envpol.2012.07.012

Lecocq A, Kryger P, Vejsnæs F, Jensen AB (2015) Weight watching and the effect of landscape on honeybee colony productivity: investigating the value of colony weight monitoring for the beekeeping industry. PLoS One 10:1-14. https://doi.org/10.1371/journal.pone. 0132473

Leita L, Muhlbachova G, Cesco S, Barbattini R, Mondini C (1996) Investigation of the use of honey bees and honey bee products to assess heavy metals contamination. Environ Monit Assess 43:1-9. https://doi.org/10.1007/BF00399566

Leśniok M (2011). Changeability of Air Pollution in Katowice Region (Central Europe, Southern Poland). In: Nejadkoorki F. (ed) Advanced Air Pollution, InTech 
Li Z, Liu W, Xu G (2018) The wisdom of honeybee defenses against environmental stresses. Front Microbiol 9:772. https://doi.org/10. 3389/fmicb.2018.00722

Long EY, Krupke CH (2016) Non-cultivated plants present a season-long route of pesticide exposure for honey bees. Nat Commun 7:11629. https://doi.org/10.1038/ncomms11629

Lorenz S, Kerstin S (2015) Saving the honeybees in Berlin? A case study of the urban beekeeping boom. Environ Sociol 1:116-126. https:// doi.org/10.1080/23251042.2015.1008383

Lowenstein DM, Matteson KC, Xiao I, Silva AM, Minor ES (2014) Humans, bees, and pollination services in the city: the case of Chicago, IL (USA). Biodivers Conserv 23:2857-2874. https://doi. org/10.1007/s10531-014-0752-0

Malaspina O, Mathias da Silva-Zacarin EC (2006) Cell markers for ecotoxicological studies in target organs of bees. Brazilian J Morphol Sci 23:303-309

Mancarella S, Pennisi G, Gasperi D, Loges V, do Nascimento C, Antisari L, Orsini F, Gianquinto G (2017) Metal(oid)s contamination in rural and urban vegetable gardens of Teresina (Brazil). Acta Hortic 1189: 465-468. https://doi.org/10.17660/ActaHortic.2017.1189.92

Manjon C, Troczka BJ, Zaworra M, Beadle K, Randall E, Hertlein G, Singh KS, Zimmer CT, Homem RA, Lueke B, Reid R, Kor L, Kohler M, Benting J, Williamson MS, Davies T, Field LM, Bass C, McGranahan G, Satterthwaite D, Tacoli C (2018) Unravelling the Molecular Determinants of Bee Sensitivity to Neonicotinoid Insecticides. Current biology. 28(7):1137-1143.e5. https://doi.org/ 10.1016/j.cub.2018.02.045

Matović K, Ćirić J, Kaljević V, Nedić N, Jevtić G, Vasković N, Baltić MŽ (2018) Physicochemical parameters and microbiological status of honey produced in an urban environment in Serbia. Environ Sci Polut Res Int 25:14148-14157. https://doi.org/10.1007/s11356018-1659-1

Maxim L, Van Der Sluijs JP (2012) Expert explanations of honeybee losses in areas of extensive agriculture in France: Gaucho® compared with other supposed causal factors. Environ Res Lett 5: 014006. https://doi.org/10.1088/1748-9326/5/1/014006

McGranahan G (2005) An overview of urban environmental burdens at three scales: intra-urban, urban-regional, and global internat. Rev Environ Strateg 5:335-356

McGranahan G, Satterthwaite D, Tacoli C (2004) Rural-urban change, boundary problems and environmental burdens. Working Paper Series on Rural-Urban Interactions and Livelihood Strategies. Working paper 10. International Institute for Environment and Development. pp. 28.

Morales M, Ramos M, Vazque P, Galiano F, Valverde M, Lopez V, Flores J, Fernandez-Alba A (2020) Distribution of chemical residues in the beehive compartments and their transfer to the honeybee brood. Sci Total Environ 10:136288. https://doi.org/10.1016/j. scitotenv.2019.136288

Morgano M, Martins M, Rabonato L, Milani R, Yotsuyanagi K, Rodriguez-Amaya D (2010) Inorganic contaminants in bee pollen from southeastern Brasil. J Agric Food Chem 58(11):6876-6883. https://doi.org/10.1021/jf100433p

Nauen R, Ebbinghaus-Kintscher U, Schmuck R (2001) Toxicity and nicotinic acetylcholine receptor interaction of imidacloprid and its metabolites in Apis mellifera (Hymenoptera: Apidae). Pest Manag Sci 57:577-586. https://doi.org/10.1002/ps.331

Negri I, Mavris C, Di Prisco G, Caprio E, Pellecchia M (2015) Honey bees (Apis mellifera, L.) as active samplers of airborne particulate matter. PLoS One 10:1-22. https://doi.org/10.1371/journal.pone. 0132491

Nikolić TV, Kojić D, Orčić S, Vukašinivić EL, Blagojević DP, Purać J (2019) Laboratory bioassays on the response of honey bee (Apis mellifera L.) glutathione $S$-transferase and acetylcholinesterase to the oral exposure to copper, cadmium, and lead. Environ Sci Pollut Res 26:6890-6897
Nowak MM, Bury A (2017) Environmental problems in Poland's agrifood sector. Studia i Prace WNEIZ US 41:217-227

Perugini M, Manera M, Grotta L, Abete M, Tarasco R, Amorena M (2011) Heavy metal ( $\mathrm{Hg}, \mathrm{Cr}, \mathrm{Cd}$, and $\mathrm{Pb}$ ) contamination in urban areas and wildlife reserves: honeybees as bioindicators. Biol Trace ElemRes 140:170-176. https://doi.org/10.1007/s12011-010-8688-z

Pettis JS, van Engelsdorp D, Johnson J, Dively G (2012) Pesticide exposure in honey bees results in increased levels of the gut pathogen Nosema. Naturwissenschaften 99:153-158. https://doi.org/10.1007/ s00114-011-0881-1

Potts SG, Roberts SPM, Dean R, Marris G, Brown MA, Jones R, Neumann P, Settele J (2010) Declines of managed honey bees and beekeepers in Europe. J Apic Res 499:15-22. https://doi.org/10. 3896/IBRA.1.49.1.02

Priftis K, Anthracopoulos MB, Patiatsos AG, Tzavelas G, NikolauPanagiotou A, Panayiotis D, Nicolaidou P, Mantzouranis E (2007) Different effects of urban and rural environments in the respiratory status of Greek schoolchildren. Respir Med 101:98-106. https://doi. org/10.1016/j.rmed.2006.04.008

Pyza E, Mak P, Kramarz P, Laskowski R (1997) Heat shock proteins (HSP70) as biomarkers in ecotoxicological studies. Ecotoxicol Environ Saf 38:244-251. https://doi.org/10.1006/eesa.1997.1595

Rachael W, Ramiro A, Diego V, Gretchen L, Aizen MA (2009) A metaanalysis of bees' responses to anthropogenic disturbance. Ecology 90:2068-2076. https://doi.org/10.1890/14-0661.1

Rand EED, Smit S, Beukes M, Apostolides Z, Pirk CWW, Nicolson SW (2015) Detoxification mechanisms of honey bees (Apis mellifera) resulting in tolerance of dietary nicotine. Sci Rep 5:1-11. https://doi. org $/ 10.1038 /$ srep 11779

Re R, Pellefrini N, Proteggente A, Pannala A, Yang M, Rice-Evans C (1999) Antioxidant activity applying an improved ABST radical cation decolorization assay. Free Radic Biol Med 26:1231-1237. https://doi.org/10.1016/S0891-5849(98)00315-3

Roberts SP, Harrison JF (1999) Mechanisms of thermal stability during flight in the honeybee Apis mellifera. J Exp Biol 202:1523-1533

Sadowska M, Gogolewska H, Pawelec N, Sentkowska A, KrasnodębskaOstrega B (2019) Comparison of the contents of selected elements and pesticides in honey bees with regard to their habitat. Environ Sci Pollut Res Int 26:371-380. https://doi.org/10.1007/s11356-0183612-8

Saibil H (2013) Chaperone machines for protein folding, unfolding and disaggregation. Nat Rev Mol Cell Biol 14:630-642. https://doi.org/ $10.1038 / \mathrm{nrm} 3658$

Scheiner R, Abramson CI, Brodschneider R, Crailsheim K, Farina W, Fuchs S, Grünewald B, Hahshold S, Karrer M, Koeniger G, Koeniger N, Menzel R, Mujagic S, Radspieler G, Schmickll T, Schneider C, Siegel AJ, Szopek M, Thenius R (2013) Standard methods for behavioural studies of Apis mellifera. J Apic Res 52: 1-58. https://doi.org/10.3896/IBRA.1.52.4.04

Słowińska M, Nynca J, Wilde J, Bạk B, Siuda M, Ciereszko A (2016) Total antioxidant capacity of honeybee haemolymph in relation to age and exposure to pesticide, and comparison to antioxidant capacity of seminal plasma. Apidologie 47:227-236. https://doi.org/10. 1007/s13592-015-0391-9

Solecki DW, Rosenzweig C, Parshall L, Pope G, Clark M, Cox J, Wiencke M (2005) Mitigation of the heat island effect in urban New Jersey, Global Environmental Change Part B: Environmental Hazards. Glob Environ Chang Part B Environ Hazards 6:39-49. https://doi.org/10.1016/j.hazards.2004.12.002

Stjernholm FST, Karlsson B, Boggs CL (2005) Age related changes in thoracic mass: possible reallocation of resources to reproduction in butterflies. Biol J Linn Soc 86:363-380

Strosnider H, Kennedy C, Monti M, Yip F (2017) Rural and Urban Differences in Air Quality, 2008-2012, and Community Drinking Water Quality, 2010-2015 — United States. MMWR Surveill Summ 66:1-10 
Szeszko A (2017) Green lungs of Poland in 2015. Central Statistical Office, Białystok

van Engelsdorp D, Meixner MD (2010) A historical review of managed honey bee populations in Europe and the United States and the factors that may affect them. J Invertebr Pathol 103:S80-S95. https://doi.org/10.1016/j.jip.2009.06.011

van Engelsdorp D, Traynor KS, Andree M, Lichtenberg EM, Chen Y, Saegerman C, Cox-Foster DL (2017) Colony collapse disorder (CCD) and bee age impact honey bee pathophysiology. PLoS One 12:e0179535. https://doi.org/10.1371/journal.pone.0179535

van Straalen NM (2003) Ecotoxicology becomes stress ecology. Environ Sci Technol 1:326-330

Wang Q, Gong X, Nakamura S, Kurihara K, Suzuki M, Sakamoto K, Miwa M, Lu SO (2009) Air pollutant deposition effect and morphological change of Cryptomeria japonica pollen during its transport in urban and mountainous areas of Japan. Environ. Health Risk 14:7789. https://doi.org/10.2495/EHR090081

Yan H, Jia H, Gao H, Guo X, Xu B (2013) Identification, genomic organization, and oxidative stress response of a sigma class glutathione $S$-transferase gene (AccGSTS1) in the honey bee, Apis cerana cerana. Cell Stress Chaperones 18:415-426. https://doi. org/10.1007/s12192-012-0394-7

Yang Y, Campbell C, Clark L, Cameron C, Paterson E (2006) Microbial indicators of heavy metal contamination in urban and rural soils. Chemosphere 63:1942-1952. https://doi.org/10.1016/j. chemosphere.2005.10.009

Yu SJ (1996) Insect glutathione $S$-transferases. Zool Stud 35:9-19

Publisher's note Springer Nature remains neutral with regard to jurisdictional claims in published maps and institutional affiliations. 